\title{
Coronin 6 Regulates Acetylcholine Receptor Clustering through Modulating Receptor Anchorage to Actin Cytoskeleton
}

\author{
Yuewen Chen, ${ }^{1,2,3}$ Fanny C.F. Ip, ${ }^{1,2,3,4}$ Lei Shi, ${ }^{1,2,3}$ Zhe Zhang, ${ }^{2}$ Huibin Tang, ${ }^{2}$ Yu Pong Ng, ${ }^{2,3,4}$ Wen-Cai Ye, ${ }^{1}$ \\ Amy K.Y. Fu, ${ }^{1,2,3,4}$ and Nancy Y. Ip I, $^{1,3,4}$ \\ ${ }^{1}$ JNU-HKUST Joint Laboratory for Neuroscience and Innovative Drug Research, Jinan University, Guangzhou 510632, Guangdong, China, ${ }^{2}$ Division of Life \\ Science and ${ }^{3}$ State Key Laboratory of Molecular Neuroscience, The Hong Kong University of Science and Technology, Clear Water Bay, Hong Kong, China, \\ and ${ }^{4}$ Guangdong Key Laboratory of Brain Science, Disease and Drug Development, HKUST Shenzhen Research Institute, Shenzhen, Guangdong, China
}

The maintenance of a high density of neurotransmitter receptors at the postsynaptic apparatus is critical for efficient neurotransmission. Acetylcholine receptors (AChRs) are neurotransmitter receptors densely packed on the postsynaptic muscle membrane at the neuromuscular junction (NMJ) via anchoring onto the actin cytoskeletal network. However, how the receptor-associated actin is coordinately regulated is not fully understood. We report here that Coronin 6, a newly identified member of the coronin family, is highly enriched at adult NMJs and regulates AChR clustering through modulating the interaction between receptors and the actin cytoskeletal network. Experiments with cultured myotubes reveal that Coronin 6 is important for both agrin- and laminin-induced AChR clustering. Furthermore, Coronin 6 forms a complex with AChRs and actin in a manner dependent on its C-terminal region and a conserved Arg ${ }^{29}$ residue at the $\mathrm{N}$ terminus, both of which are critical for the cytoskeletal anchorage of AChRs. Importantly, in vivo knockdown of Coronin 6 in mouse skeletal muscle fibers leads to destabilization of AChR clusters. Together, these findings demonstrate that Coronin 6 is a critical regulator of AChR clustering at the postsynaptic region of the NMJs through modulating the receptor-anchored actin cytoskeleton.

Key words: acetylcholine; actin-binding proteins; actin cytoskeleton; Coronin 6

\section{Introduction}

The neuromuscular junction (NMJ), which is formed between the motor nerve terminal and skeletal muscle membrane, is responsible for neuromuscular transmission and muscle activity (Sanes and Lichtman, 1999, 2001; Wu et al., 2010). To ensure efficient synaptic transmission, acetylcholine receptors (AChRs), the neurotransmitter receptors at the NMJ, need to be confined to the postsynaptic muscle membrane.

At mature NMJs, the AChR clusters exhibit a pretzel-like multibranched morphology that is dependent on the highly coordinated regulation of the formation, maintenance, and dispersal of the AChR clusters. Notably, AChR cluster stability is tightly controlled by their anchorage to the postsynaptic actin cytoskeleton (Dai et al., 2000; Dobbins et al., 2006). Agrin, a nerve-derived

Received July 25, 2013; revised Dec. 22, 2013; accepted Dec. 28, 2013.

Author contributions: Y.C., Y.P.N., A.K.Y.F., and N.Y.I. designed research; Y.C., F.C.F.I., Z.Z., and H.T. performed research; W.-c.Y. and N.Y.I. contributed unpublished reagents/analytic tools; Y.C., F.C.F.I., H.T., Y.P.N., A.K.Y.F., and N.Y.I. analyzed data; Y.C., F.C.F.I., L.S., A.K.Y.F., and N.Y.I. wrote the paper.

This work was supported in part by the Research Grants Council of Hong Kong (HKUST661109 and HKUST661309; Theme-based Research Scheme T13-607/12R), the National Key Basic Research Program of China (2013 CB530900), the National Natural Science Foundation of China for Young Scholars of China (Grant 81101015), the Innovation and Technology Fund for State Key Laboratory (ITCPT/17-9), the Shenzhen Peacock Plan, and the S.H. Ho Foundation. The authors declare no competing financial interests.

Correspondence should be addressed to Dr. Nancy Y. Ip, Hong Kong University of Science and Technology, Clear Water Bay, Hong Kong, China. E-mail: boip@ust.hk.

DOI:10.1523/JNEUROSCI.3226-13.2014

Copyright $\odot 2014$ the authors $\quad 0270-6474 / 14 / 342413-09 \$ 15.00 / 0$ heparin sulfate proteoglycan, and laminin, a muscle-derived extracellular matrix protein, are two critical extracellular signals that control the formation and stabilization of the AChR clusters. Agrin and laminin transduce signaling pathways via a plethora of adaptor and actin-regulating proteins, such as rapsyn, dystrophin-associated protein complex, and Rho family GTPases, strengthening the actin cytoskeletal linkage of the AChR clusters (Wu et al., 2010; Shi et al., 2012). Meanwhile, Cdk5, ephexin1, and cofilin play important roles in receptor disassembly and turnover by destabilizing the actin cytoskeleton or increasing actin dynamics (Sadasivam et al., 2005; Lee et al., 2009; Shi et al., 2010). These lines of evidence suggest that the reconstruction of the cytoskeletal anchorage of the receptors is a key process during the development of NMJs. Therefore, understanding the coordinated regulation of the receptor-associated cytoskeletal network is a prerequisite for elucidating the molecular basis of AChR clustering and NMJ development.

Coronins are a family of conserved actin-binding proteins originally identified in the actin-rich structure of the amoeba Dictyostelium discoideum (de Hostos et al., 1991). To date, seven coronins have been identified in mammals; most exhibit tissuespecific distribution patterns. In vitro studies demonstrate that coronins are involved in diverse biological processes dependent on actin cytoskeletal reorganization, including cell morphogenesis, cell migration, and endocytosis (Uetrecht and Bear, 2006; 
A

B

NE

$1 \quad$ Seven-bladed $\beta$-propeller

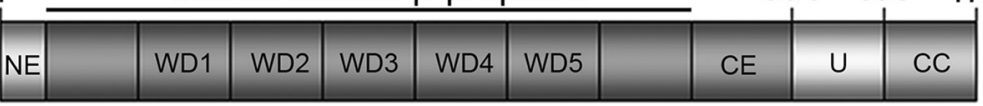

$391 \quad 430 \quad 472$

Hidden repeat 1

60

50

VEAGGGAF

rCoro6 $r$ Coro1A
Consensus MSRQVVRSSKFR:H VFGOP

WD1

90

100

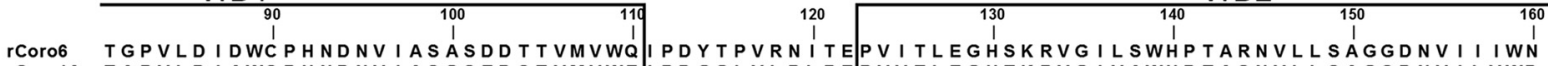

120

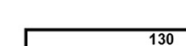

130

140

WD2 rCoro1A TAPVLD I AWCPHNDNV I ASGSEDCTVMVWE I PDGGLVLPLREPVVTLEGHTKRVG IVAWHPTAQNVLLSAGCDNVILVWD

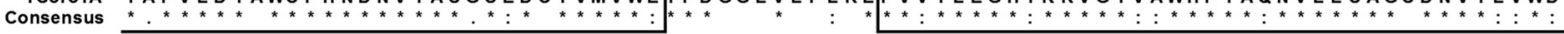

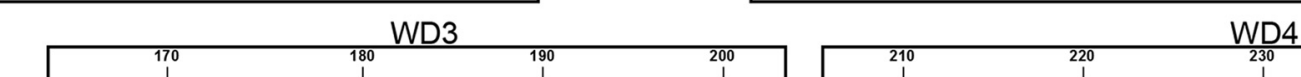

rCoro6 VGTGEVLLSL-DDIHPDVIHSVCWNSNGSLLATTCKDKTLR I I DRRKSQVVAERFAAHEGMRPMRAVFTRLGHIFTTGFT

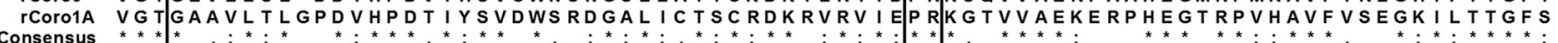

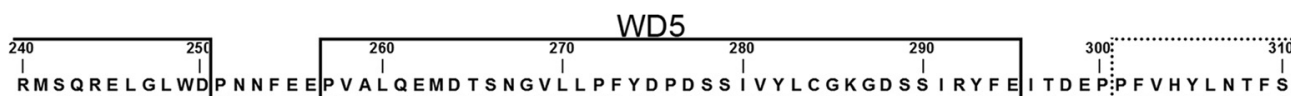

rCoro6 RMSQRELGLWDPNNFEEPVALQEMDTSNGVLLPFYDPDSS IVYLCGKGDSSIRYFE ITDEP PFVHYLNTFSSKEPQRGMG

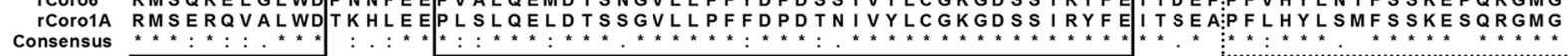

\section{Hidden repeat 2}

320

330.130

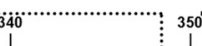

$\mathrm{CE}$

360

370

30

380

rCoro6 FMPKRGLDVSKCEIARFYKLHERKCEPIVMTVPRKSDLFQDDLYPDTPGPEPALEADEWLSGQDAEPVLISLKEGYVPPK

rCoro1A YMPKRGLEVNKCEIARFYKLHERKCEPIAMTVPRKSDLFQEDLYPPTAGPDPALTAEEWLSGRDAGPLLISLKDGYVPPK Consensus

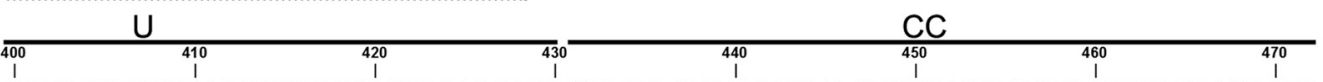

rCoro6 HREFRVTKRNILDVRPPASPRRSQSASEAPLSQQHTLETLLEEMKALRERVQAQEERITALENMLCELVDGTD 472

rCoro1A SRELRVNRGLDS - ARRRATPEPSSTLSS..... - DTVSRLEEDVRNLNA IVQKLQERLDRLEETVQAK . . . . 461

C Consensus

\begin{tabular}{|c|c|c|c|c|}
\hline $\begin{array}{c}\text { Homo } \\
\text { sapiens }\end{array}$ & $\begin{array}{c}\text { Mus } \\
\text { musculus }\end{array}$ & $\begin{array}{c}\text { Rattus } \\
\text { norvegicus }\end{array}$ & $\begin{array}{c}\text { Xenopus } \\
\text { tropicalis }\end{array}$ & $\begin{array}{c}\text { Danio } \\
\text { rerio }\end{array}$ \\
\hline $100 \%$ & $97 \%$ & $96 \%$ & $80 \%$ & $76 \%$ \\
\hline
\end{tabular}

D

\begin{tabular}{|c|c|c|c|c|c|c|}
\hline & Coro1A & Coro1B & Coro1C & Coro2A & Coro2B & Coro7 \\
\hline Coro6 & $67 \%$ & $69 \%$ & $69 \%$ & $42 \%$ & $46 \%$ & $32 \%$ \\
\hline
\end{tabular}

$\mathbf{E}$

$\mathbf{F}$
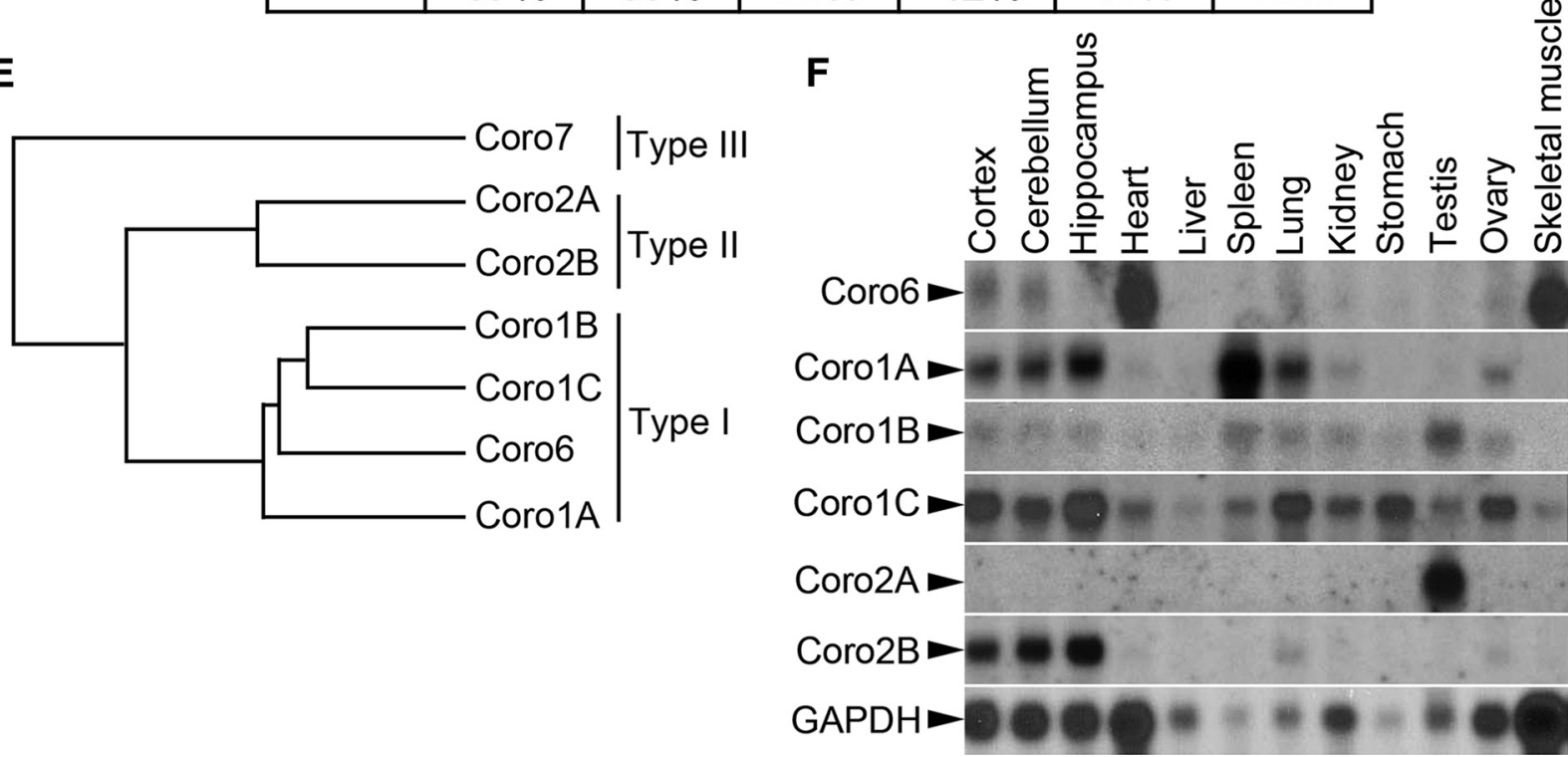

Figure 1. Identification of Coronin 6 as a muscle-specific coronin family member. A, Schematic diagram of Coronin 6 domains showing the N-terminal extension (NE), seven-bladed $\beta$-propeller domain comprising 5 canonical WD40 repeats (WD), conserved C-terminal extension (CE), unique region (U), and coiled-coil domain (CC). $\boldsymbol{B}$, Protein sequence alignment of rat Coronin 6 (rCoro6) with rat Coronin $1 \mathrm{~A}(\mathrm{rC}$ oro1A) generated by Clustal 0 mega. Solid black boxes represent the five predicted WD40 repeats, and dashed boxes represent two "hidden" repeats. C, Percentages of amino acid identities of Coronin 6 among different species. D, Percentages of amino acid identities between rCoro6 and other rat coronin proteins. E, Phylogenetic tree of mammalian coronin family generated by Clustal 0 mega. $\boldsymbol{F}$, The tissue expression pattern of mammalian coronins in adult rats was revealed by northern blotting. 


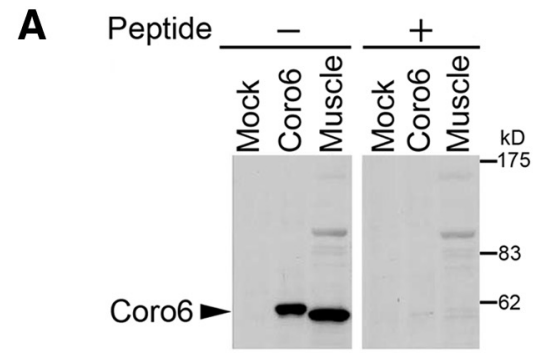

D

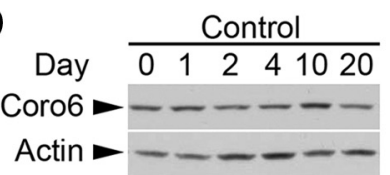

$\mathbf{F}$

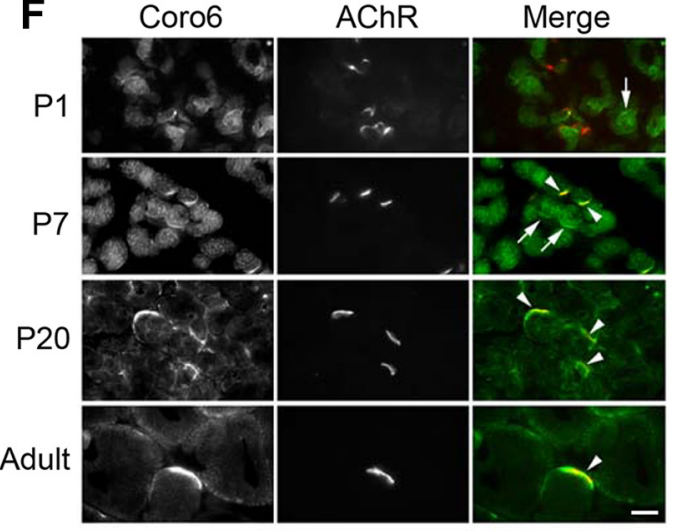

Crush

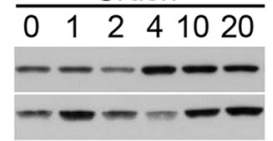

B

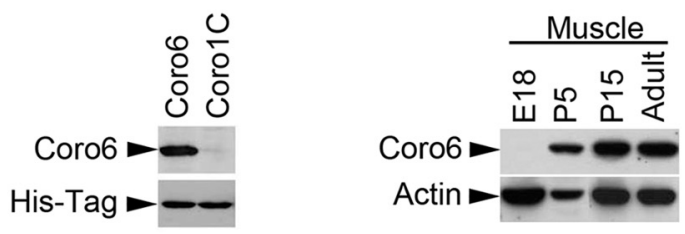

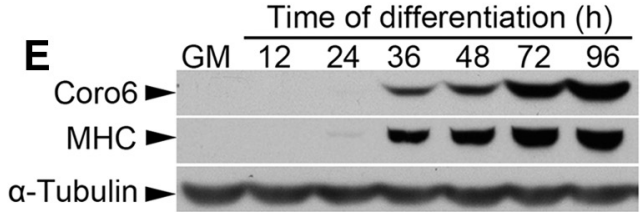

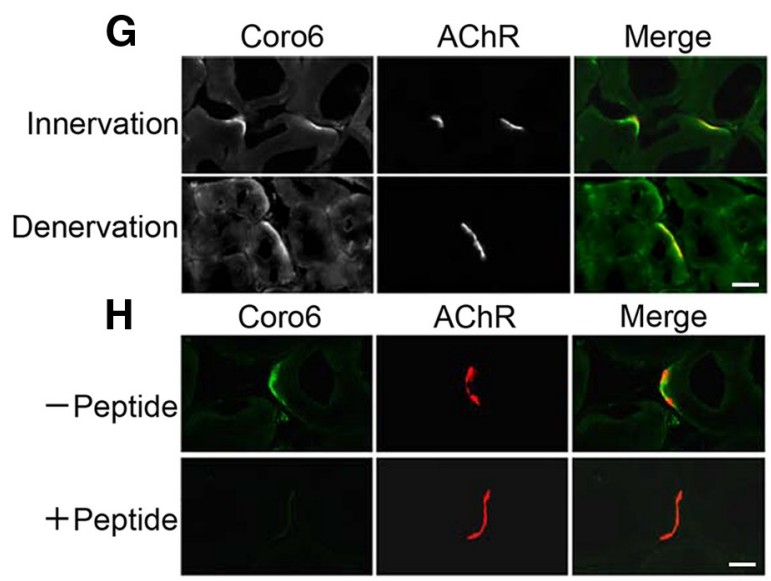

Figure 2. High concentrations of Coronin 6 at the NMJ.A, B, Specificity of Coronin 6 polyclonal antibody. Rabbit Coronin 6 polyclonal antibody recognized both the overexpressed Coronin 6 (Coro6) and endogenous Coronin 6 in adult rat muscle (Muscle) ( $A$, left). This recognition was blocked by preincubation with the peptide antigen (A, right). Western blot analysis of COS-7 cells with ectopic expression of His-tagged Coro1C and Coro6 using the Coronin 6 polyclonal antibody $(\boldsymbol{B})$. C, Coronin 6 protein expression in rat muscle during development was determined by Western blotting. $\boldsymbol{D}$, Western blot analyses of Coronin 6 (20 $\mu \mathrm{g}$ per lane) were performed using rat gastrocnemius muscle after sciatic nerve crushing. Actin served as a loading control. $\boldsymbol{E}_{\text {, }} \mathrm{C}(\mathrm{C} 12 \mathrm{myoblasts}$ in growth media (GM) or myotubes in differentiation media for the indicated times (h) were lysed and subjected to Western blotting to examine Coronin 6 protein expression. $\boldsymbol{F}$, Coronin 6 was concentrated at the motor endplates during development (postnatal stages, from P1 to P21). Rat skeletal muscle sections were costained with antibody against Coronin 6 and AlexaFluor-555-conjugated $\alpha$-BTX to visualize AChRs. Scale bar, $10 \mu \mathrm{m}$. Arrowheads indicate Coronin 6 staining colocalized with AChRs; arrows indicate Coronin 6 not colocalized with AChRs. G, Coronin 6 was localized at the postsynaptic muscle membrane of gastrocnemius muscle after nerve denervation. Scale bar, $10 \mu \mathrm{m}$. $\boldsymbol{H}$, The immunoreactivity of Coronin 6 antibody was abolished by preabsorption with its peptide antigen. Scale bar, $10 \mu \mathrm{m}$.

Chan et al., 2011). Coronin 1A, the best-characterized coronin, is essentially expressed in thymocytes, T cells, macrophages, and neutrophils and plays important roles in pathogen survival in phagocytes and homeostatic T-cell signaling (Föger et al., 2006; Mueller et al., 2008; Pieters et al., 2013). Nonetheless, the physiological functions of other coronins remain poorly understood.

We previously reported that Coronin 6, a novel coronin protein family member, is differentially regulated in muscle after denervation (Tang et al., 2000). In the present study, we show that Coronin 6 is prominently expressed in adult muscle and enriched at the NMJ. Studies with cultured myotubes reveal that Coronin 6 regulates both agrin- and laminininduced AChR clustering and is important for anchoring AChRs onto the actin cytoskeleton. We also show that both the C-terminal region and a conserved $\mathrm{Arg}^{29}$ residue at the $\mathrm{N}$ terminus of Coronin 6 are essential for its actin-binding activity and stabilization of AChR-cytoskeleton linkage. Together, these findings demonstrate that Coronin 6 is a critical regulator of AChR clustering through modulating the receptorassociated actin cytoskeleton.

\section{Materials and Methods}

Reagents. Anti-phosphotyrosine (4G10) antibody was purchased from Millipore, and anti-FLAG and anti-actin antibodies were from SigmaAldrich. The anti-AChR $\beta$ antibody was as described previously (Shi et al., 2010). AlexaFluor-555- or biotin-conjugated $\alpha$-bungarotoxin ( $\alpha$ BTX), and natural mouse laminin were from Invitrogen. Recombinant rat C-terminal agrin was from R\&D Systems. Small interfering RNA (siRNA) against mouse Coronin 6 (5' -CAAGCAACGGAGTGTTA CTACCATT- $3^{\prime}$ ) and a control siRNA against luciferase (5'-CGTA CGCGGAATACTTCGA-3') were synthesized by Invitrogen. The shRNA target sequence for mouse Coronin 6 was $5^{\prime}$-CGGAGTGTTA CTACCATTC- $3^{\prime}$.

Animals. All animals including rats and mice were bred in the Animal and Plant Care Facility of the Hong Kong University of Science and Technology and handled in accordance with the Animals (Control of Experiments) Ordinance of Hong Kong.

Northern blot analysis. Different tissues from adult male Sprague Dawley rats were collected and frozen using liquid nitrogen. Total RNA was extracted and subsequently analyzed by northern blotting as described previously (Ip et al., 1995). The cDNA fragments of different coronins were labeled using the Megaprime labeling kit 
(GE Healthcare). The results of the northern blot analysis were confirmed in at least 3 experiments.

Cloning of Coronin 6 cDNA and its mutants. The full-length cDNA of Coronin 6 was obtained by rapid amplification of $5^{\prime}$ and $3^{\prime}$ cDNA ends according to the manufacturer's instructions (RACE Kit, Invitrogen). Different cDNA expression constructs, including C-terminal GST-tagged rat Coronin 6, C-terminal FLAGtagged mouse Coronin 6 (WT), Coronin 6 mutant with deletion of coiled-coil domain $(\Delta \mathrm{CC})$, and Coronin 6 mutant with deletion of both the unique region and coiled-coil domain ( $\triangle$ UCC) were subcloned using PCR amplification. Coronin 6 mutants in which $\operatorname{Arg}^{29}$ was substituted with Ala or Asp (R29A/D) were constructed by PCR-based site-directed mutagenesis as described previously (Aiyar et al., 1996).

Generation of Coronin 6 antibody. A specific Coronin 6 polyclonal antibody was raised against a 25 -amino acid synthetic peptide corresponding to a variable region from $\mathrm{L}^{411}$ to $\mathrm{T}^{435}$ (LDVRPPASPRRSQSASEAPLSQQHT) in rabbits (Research Genetics). The antibodies in the serum were then affinity purified using a SulfoLink affinity column (Pierce) according to the manufacturer's instructions. The specificity of the antibody was confirmed by Western blot analysis using antibody preabsorbed with the synthetic peptide. The cross-reactivity of Coronin 6 antibody was further confirmed by its inability to detect Coronin 1C, a highly homologous coronin protein.

Denervation and Western blot analysis. Sixweek-old male Sprague Dawley rats were anesthetized with isoflurane, and their sciatic nerves were crushed using forceps prechilled in liquid nitrogen (Ip et al., 1996). Total protein extracted from denervated muscles and limb muscles of rats at different developmental stages was analyzed by Western blotting as described previously (Fu et al., 1999). Minced rat muscle was homogenized in lysis buffer $(20$ mм Tris, pH 7.6, $150 \mathrm{~mm} \mathrm{NaCl}, 1$ mм EDTA, 1 $\mathrm{mm}$ EGTA, and $5 \mathrm{~mm} \mathrm{NaF}$ ) with protease inhibitors (1 mM PMSF, $5 \mathrm{~mm}$ benzamidine, 10 $\mu \mathrm{g} / \mathrm{ml}$ leupeptin, $10 \mu \mathrm{g} / \mathrm{ml}$ aprotinin, $10 \mu \mathrm{g} / \mathrm{ml}$ trypsin inhibitor, $2 \mu \mathrm{g} / \mathrm{ml}$ antipain, and $1 \mathrm{~mm}$ $\mathrm{NaVO}_{3}$ ) using Polytron. The homogenate was supplemented with equal volume of lysis buffer containing $2 \% \mathrm{NP}-40$ and incubated at $4^{\circ} \mathrm{C}$ for $30 \mathrm{~min}$. The lysate was centrifuged at $12,000 \times$ $g$ at $4^{\circ} \mathrm{C}$ for $15 \mathrm{~min}$. The supernatant was collected, and $20 \mu \mathrm{g}$ total proteins were subjected to Western blot analysis. Protein samples were fractionated by SDS-PAGE and electrotransferred to nitrocellulose membranes. Immunoblotting was performed with Coronin 6 antibody or actin antibody. Horseradish peroxidaseconjugated secondary antibody was used to detect reactive bands using the Pico detection kit (Pierce).

Immunohistochemical analyses. Adult rat muscle sections $(10 \mu \mathrm{m})$ were fixed with $2 \%$ paraformaldehyde/5\% sucrose in PBS at room temperature for $15 \mathrm{~min}$. Sections were then washed and permeabilized with $0.4 \%$ Triton X-100. Double staining was performed by incubating the sections with AlexaFluor-555-conjugated $\alpha$-BTX (Invitrogen) and Coronin 6 antibody overnight at $4^{\circ} \mathrm{C}$ followed by FITC-conjugated goat anti-rabbit antibody in $\mathrm{PBS} / 10 \% \mathrm{FBS}$ for $1 \mathrm{~h}$ at $37^{\circ} \mathrm{C}$. The sections were
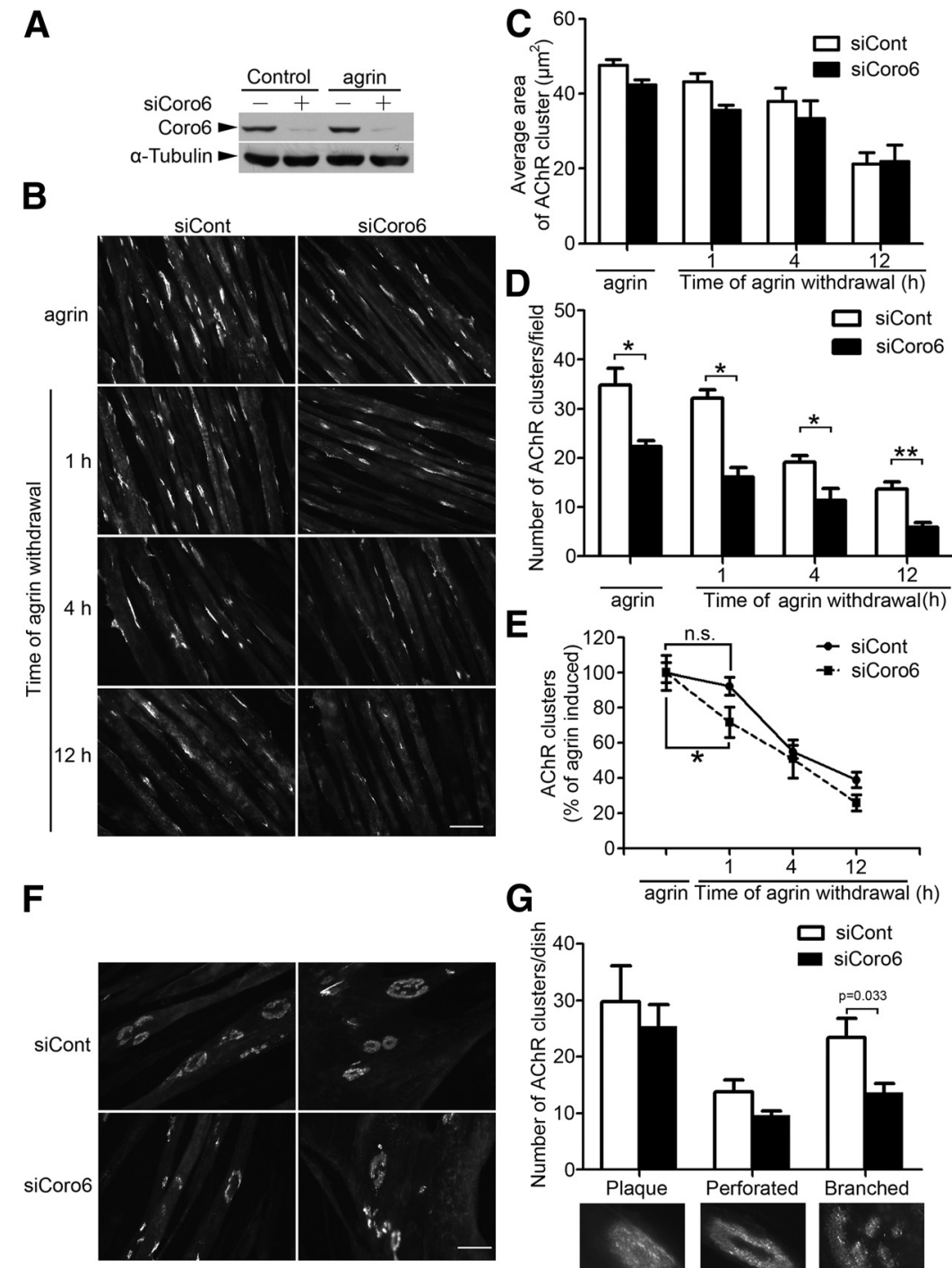

G

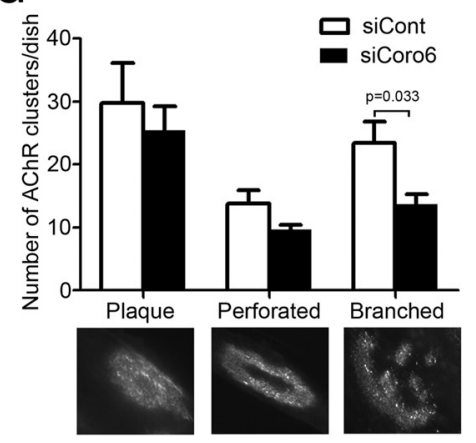

Figure 3. Regulation of AChR clustering in myotubes by Coronin 6. A, C2C12 myotubes were transfected with siRNA against Coronin 6 (siCoro6) or luciferase as a control (siCont). Cell lysates were subjected to immunoblotting with antibodies against Coronin 6 or $\alpha$-tubulin. B-D, Coronin 6 regulates agrin-induced AChR clustering. C2C12 myotubes were transfected with siCoro6 or siCont followed by stimulation with agrin for $12 \mathrm{~h}$ to induce AChR clustering. For AChR dispersal, AChR clusters on agrin-treated myotubes were labeled with $\alpha$-BTX. Myotubes were subsequently washed and maintained in agrin-free medium for an additional 1,4 , or $12 \mathrm{~h}$. Representative images $(\boldsymbol{B})$, and quantification of the size $(\boldsymbol{C})$ and number $(\boldsymbol{D})$ of $A C h R$ clusters on myotubes from each condition. The mean \pm SEM of at least 3 experiments is indicated. ${ }^{*} p<0.05$, siCoro6 versus siCont (Student's $t$ test). ${ }^{* *} p<0.01$, siCor06 versus siCont (Student's $t$ test). Scale bar, $50 \mu \mathrm{m}$. $\boldsymbol{E}$, The percentage of AChR clusters was calculated by normalizing the number of $A C h R$ clusters at different time points after agrin withdrawal to that at baseline. ${ }^{*} p<0.05$, percentage of $A C h R$ clusters at the first hour of agrin withdrawal versus that at baseline in Coronin 6-silenced myotubes. n.s., Not significant. $\boldsymbol{F}, \mathrm{C} 2 \mathrm{C} 12$ myoblasts were cultured on laminin-coated plates and fused for $2 \mathrm{~d}$, and the myotubes were subsequently transfected with siCoro6 or siCont. AChR clusters were visualized by AlexaFluor-555-conjugated $\alpha$-BTX. Three types of AChR clusters are shown: plaque, perforated, and branched clusters. $\mathbf{G}$, The numbers of each type of AChR cluster were counted from at least three individual experiments (branched clusters: siCont, $23.4 \pm 3.4$; siCor06, $13.6 \pm 1.6$ ). $p=0.033$, siCoro6 versus siCont (Student's $t$ test).

then washed and mounted for confocal microscopic analysis (BX51, Olympus).

Cell culture and transfection. C2C12 myoblasts were maintained in Dulbecco's modified Eagle medium (DMEM) supplemented with 20\% FBS and differentiated by switching the medium to $2 \%$ horse serum. For the siRNA knockdown experiment, myotubes on day 2 were transfected with $10 \mathrm{nmol}$ siRNA against mouse Coronin 6 or luciferase gene (as a control) using Lipofectamine 2000 (Invitrogen). The transfected myotubes were stimulated with $10 \mathrm{ng} / \mathrm{ml}$ agrin to induce AChR clustering. To express the deletion mutants of Coronin 6 on mature myotubes, the mRNAs of these mutants were first generated by in vitro transcription 


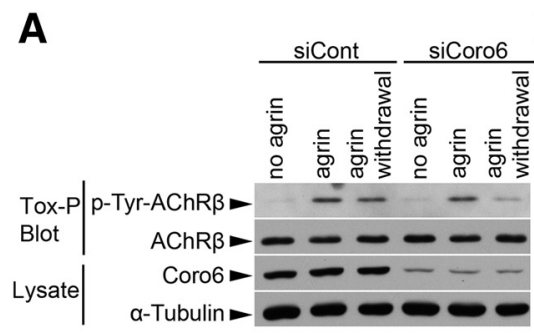

\section{B}

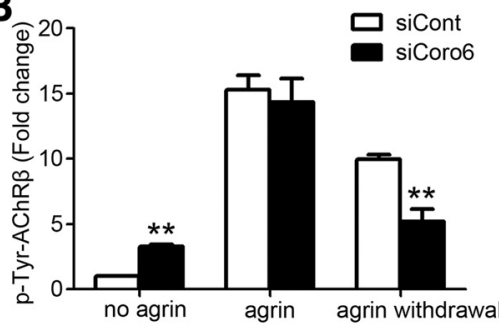

C

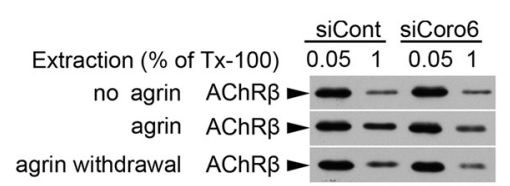

$\mathbf{E}$

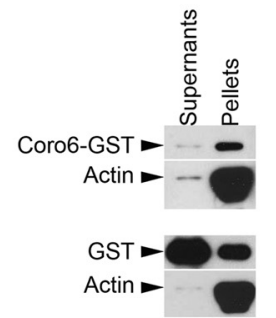

D

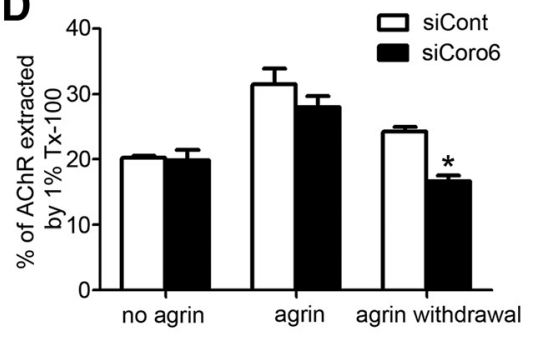

$\mathbf{F}$

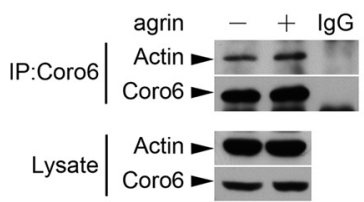

\section{G}

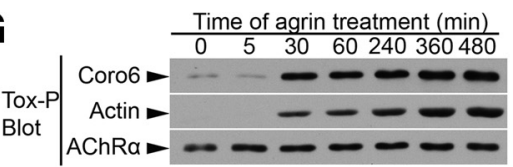

Figure 4. Association of Coronin 6 with AChR-actin complex upon agrin stimulation. A, Tyrosine phosphorylation level of AChR $\beta$ subunit in Coronin 6-knockdown myotubes. Coronin 6-knockdown myotubes were treated overnight with agrin, and cells were washed and incubated with agrin-free medium for $4 \mathrm{~h}$. AChRs were precipitated with biotin-labeled $\alpha$-BTX (Tox-P) and subsequently subjected to Western blot analysis using anti-4G10 antibody ( $p-$ Tyr-AChR $\beta$ ). AChR $\beta$ was used as a loading control. $B$, Quantification of the fold change of $p$-Tyr-AChR $\beta$ levels (normalized to AChR $\beta$ ) from three individual experiments. ${ }^{*} p<0.05$, siCoro6 versus siCont (Student's $t$ test). ${ }^{* *} p<0.01$, siCoro6 versus siCont (Student's $t$ test). C, AChR extractability assay shows the linkage of AChR to the cytoskeleton after Coronin 6 knockdown. Myotubes were subjected to sequential extraction using different concentrations of Triton X-100. AChRs in the two fractions were precipitated by Tox-P, followed by Western blot analysis for the AChR $\beta$ subunit. $D$, Percentages of AChR $\beta$-subunit extracted from the $1 \%$ Triton X-100 fraction. Quantification was performed in three individual experiments. ${ }^{*} p<0.05$, siCoro6 versus siCont (Student's $t$ test). $\boldsymbol{E}$, Actin cosedimentation assay. Coronin 6 and F-actin coprecipitated prominently in the pellet fraction but not the supernatants. $F$, Coimmunoprecipitation demonstrates Coronin 6 interacts with actin in $\mathrm{C}^{2} \mathrm{C} 12$ myotubes. G, Agrin treatment stimulated the recruitment of Coronin 6 to AChR clusters together with actin. Myotubes were treated with agrin for the indicated time periods. AChRs were precipitated by Tox-P followed by Coronin 6 (Coro6), actin, and AChR $\alpha$ immunoblotting.

using the mMESSAGE mMACHINE T7 Ultra Kit (Invitrogen); these mRNAs were subsequently transfected into myotubes using Lipofectamine 2000.

AChR clustering assay. C2C12 myotubes were treated with agrin (10 $\mathrm{ng} / \mathrm{ml}$ ) for $12 \mathrm{~h}$ to induce AChR clustering, which was then visualized by AlexaFluor-555-conjugated $\alpha$-BTX. To examine the dispersal of AChR clusters, myotubes were first treated with agrin for $12 \mathrm{~h}$ and AChRs were labeled with $\alpha$-BTX. The myotubes were subsequently washed twice and maintained in fresh agrin-free medium for another 12-14 h. To quantify AChR clusters, AChR clusters from $>10$ random fields per dish were imaged by fluorescence microscopy $(n=3$ dishes from 3 independent experiments; $40 \times$ magnification; Leica). AChR clusters were quantified using MetaMorph IMAGE ANALYSIS software. Only AChR clusters with length $>5 \mu \mathrm{m}$ were counted.

To induce pretzel-like clusters, C2C12 myoblasts were cultured and differentiated on laminin-coated dishes as described previously (Kummer et al., 2004). Briefly, before cell seeding, the dishes were coated with $5 \mu \mathrm{g} / \mathrm{ml}$ polyornithine (Sigma-Aldrich) in distilled water for $30 \mathrm{~min}$, air dried, and incubated with $10 \mu \mathrm{g} / \mathrm{ml}$ laminin in Dulbecco's PBS (D-PBS) overnight at $37^{\circ} \mathrm{C}$. The dishes were washed with D-PBS 3 times before plating the cells. Myoblasts were grown to $90 \%$ confluence and switched to DMEM containing $2 \%$ horse serum to induce fusion.

AChR precipitation and extractability assay. $\mathrm{C} 2 \mathrm{C} 12$ myotubes were harvested in lysis buffer (50 mm Tris- $\mathrm{HCl}, \mathrm{pH} 8.0,50 \mathrm{~mm} \mathrm{NaCl}, 5 \mathrm{~mm}$ EDTA, 5 mm EGTA, $5 \mathrm{~mm} \mathrm{NaF}$, and 0.5\% Triton $\mathrm{X}-100$ with protease inhibitors $[1 \mathrm{~mm}$ PMSF, $5 \mathrm{~mm}$ benzamidine, $10 \mu \mathrm{g} / \mathrm{ml}$ leupeptin, $10 \mu \mathrm{g} / \mathrm{ml}$ aprotinin, $10 \mu \mathrm{g} / \mathrm{ml}$ trypsin inhibitor, $2 \mu \mathrm{g} / \mathrm{ml}$ antipain, and $\left.1 \mathrm{~mm} \mathrm{Na}_{3} \mathrm{VO}_{4}\right]$ ). The lysate was collected, and AChRs were precipitated using biotin-conjugated $\alpha$-BTX followed by Western blot analysis for p-Tyr$\operatorname{AChR} \beta, \operatorname{AChR} \beta, \operatorname{AChR} \alpha$, actin, and Coronin 6. The AChR extractability assay was performed as described previously (Sadasivam et al., 2005).

Actin cosedimentation assay. For actin cosedimentation, skeletal muscle actin (Sigma-Aldrich) was resuspended in actin polymerization buffer (10 mm Tris-HCl, pH 8.0, 100 mm KCl, 0.5 mm dithiothreitol, $0.2 \mathrm{~mm} \mathrm{ATP,} 1 \mathrm{mM} \mathrm{MgCl}_{2}$, and 0.2 $\mathrm{mm} \mathrm{CaCl}$ ). GST-Coronin 6 fusion protein or GST was incubated with actin $(1 \mathrm{mg} / \mathrm{ml})$ in the presence of actin polymerization buffer for $1 \mathrm{~h}$ at $25^{\circ} \mathrm{C}$ and subsequently ultracentrifuged at $100,000 \times g$ for $30 \mathrm{~min}$ at $4^{\circ} \mathrm{C}$. Supernatants and pellets were resolved by SDS-PAGE and visualized using Western blot analysis.

Electroporation and whole-mount analysis. The tibialis anterior muscles of 4-week-old C57BL/6J male mice were injected with $30 \mu \mathrm{l}$ plasmids containing $5 \mu \mathrm{g}$ GFP and $30 \mu \mathrm{g}$ pSUPER or shCoro6 using a 29-gauge needle. Immediately after injection, electroporation with 8 electric pulses $(90 \mathrm{~V}, 20 \mathrm{~ms}, 980$ ms apart) was applied via a pair of electrodes covering the injection sites. Three weeks after electroporation, the animals were anesthetized and electroporated muscles were dissected, fixed with $4 \%$ paraformaldehyde for $30 \mathrm{~min}$, and immunostained with AlexaFluor-555-conjugated $\alpha$-BTX overnight at $4^{\circ} \mathrm{C}$. Fluorescent images were taken using a Zeiss LSM710 confocal microscope.

Statistical analysis. All quantitative data were analyzed by GraphPad Prism 5. Statistically significant differences between 2 groups were determined by Student's $t$ test. Differences between multiple groups were analyzed by one-way ANOVA. The level of significance was set at $p<$ 0.05 .

\section{Results}

Identification of Coronin 6 as a muscle-specific coronin family member

As part of our efforts to identify important regulators during NMJ development, we previously reported the identification of a set of candidate genes that are differentially regulated in rat skeletal muscle upon denervation (Tang et al., 2000). One of these genes remarkably upregulated by denervation shares high homology with the coronin family. The full-length coding sequence of this gene was submitted to the NCBI GenBank as a coronin relative protein (accession number: AF140359) and subsequently designated Coronin 6 (Coro6, NM_139115). Rat Coro6 cDNA contains a 1419-nucleotide open reading 
frame that encodes a 472-amino acid protein. Similar to other members of the coronin family, Coronin 6 is a sevenbladed $\beta$-propeller protein that contains five WD40 repeats, two hidden atypical repeats, a conserved C-terminal extension, a variable unique region, and a coiled-coil domain at the end of the cytoplasmic tail (Fig. 1A,B).

Mammalian coronins are divided into three classes on the basis of sequence homology: Type I (Coronin 1A, $1 \mathrm{~B}, 1 \mathrm{C}$ ), Type II (Coronin $2 \mathrm{~A}$ and $2 \mathrm{~B}$ ), and Type III (Coronin 7) (de Hostos, 1999; Uetrecht and Bear, 2006; Chan et al., 2011). Amino acid sequence alignment showed that Coronin 6 exhibits a high degree of sequence conservation across various species (Fig. 1C) and is more homologous to Type I coronins (67-69\% identity) than Type II or III coronins (32-42\% identity) (Fig. 1D). Phylogenetic analysis further confirmed Coronin 6 as the fourth member of Type I coronins (Fig. 1E). Interestingly, although different coronins exhibit distinct tissue distribution patterns, Coronin 6 is the only coronin member that was prominently expressed in skeletal muscle and heart (Fig. $1 F$ ).

\section{Coronin 6 protein is highly concentrated at the NMJ}

To study the biological function of Coronin 6 , a polyclonal antibody against its unique region was generated. The specificity of the antibody was demonstrated by the lack of cross-reactivity with Coronin $1 \mathrm{C}$, a closely related Type I coronin (Fig. $2 A, B$ ). Similar to the change in its transcript level (Tang et al., 2000), the protein expression of Coronin 6 was upregulated in skeletal muscle during development and after denervation (Fig. 2C,D). Furthermore, Coronin 6 was only prominently detected when C2C12 myoblasts differentiated into myotubes, similar to the temporal expression profile of myosin heavy chain (Fig. 2E).

Given that Coronin 6 is regulated by muscle differentiation and neural activity, we subsequently investigated its localization at the NMJ. Immunohistochemical analysis revealed that Coronin 6 protein began to colocalize with AChR clusters at P7 and was confined to the NMJ at P20 (Fig. 2F). Importantly, Coronin 6 protein remained colocalized with AChRs after denervation, indicating that the localization of Coronin 6 at the postsynaptic sites was not affected by the loss or gain of neural/nerve activity (Fig. $2 G$ ). The immunoreactivity of Coronin 6 antibody was confirmed to be specific because the signal was blocked by its peptide antigen (Fig. 2H).
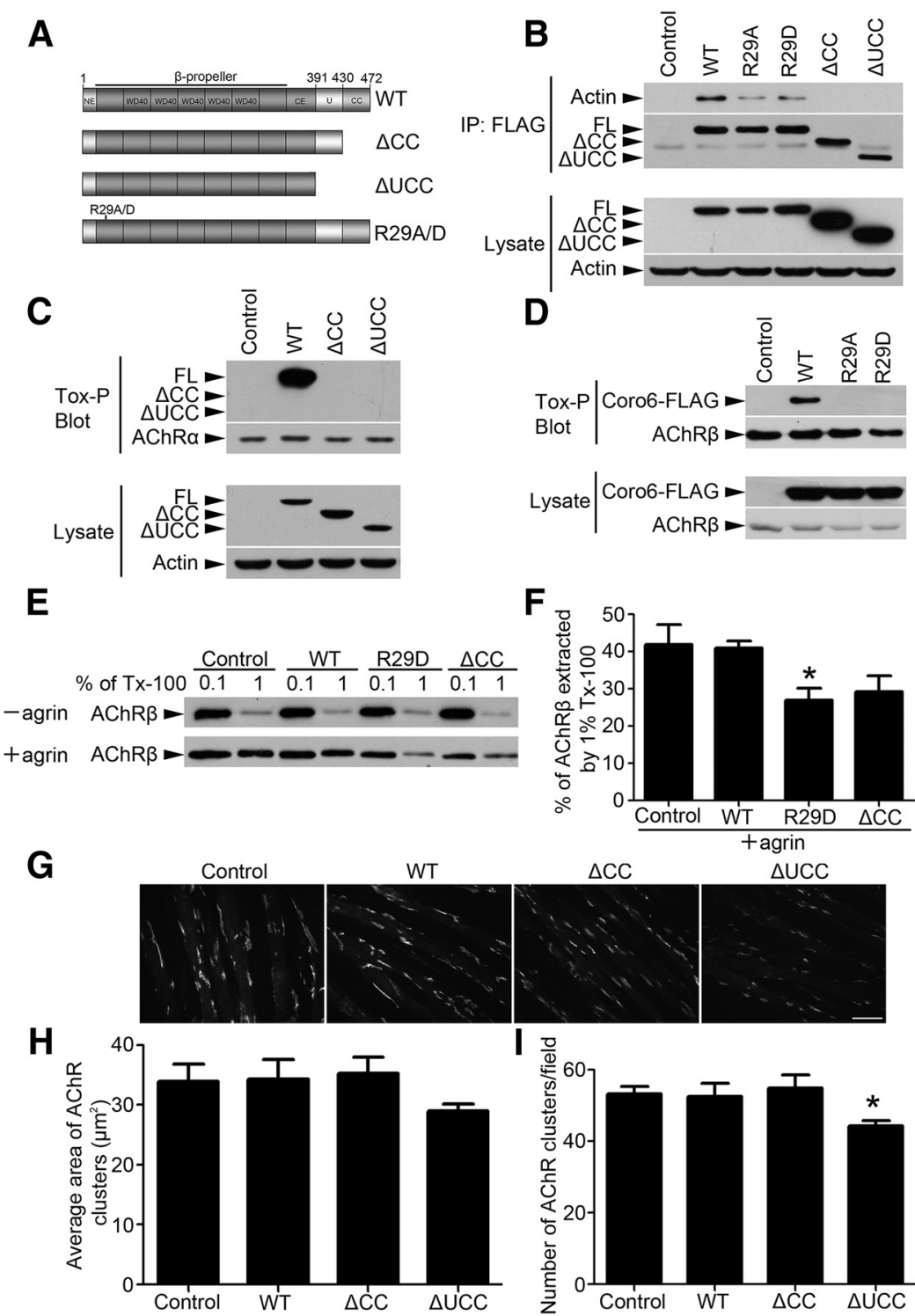

$\triangle \mathrm{CC}$

$\triangle \mathrm{UCC}$

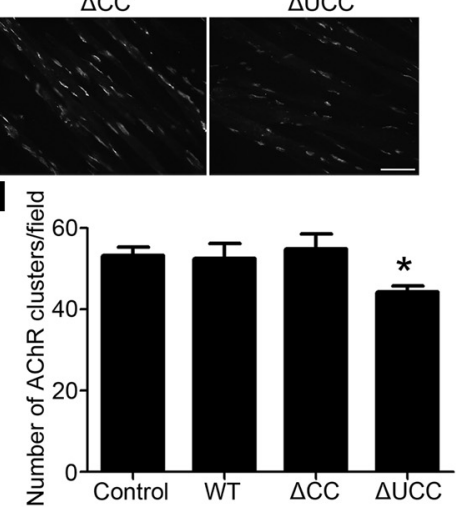

Figure 5. Requirement of the actin-binding activity of Coronin 6 for its association with AChR clusters. $A$, Schematic diagram of Coronin 6 and its mutants. $\boldsymbol{B}$, Interactions between Coronin 6 and its deletion and point mutants with actin in HEK293T cells. FLAG-tagged Coronin 6 and its mutants were overexpressed in HEK293T cells, and the protein was coimmunoprecipitated with anti-FLAG antibody. C-terminal FLAG-tagged Coronin 6 (WT; full-length [FL]), $\Delta C C$ mutant, $\Delta U C C$ mutant, or R29A/D mutant. C, D, The deletion of the coiled-coil domain or R29A/D mutants disrupted the association between Coronin 6 and AChRs. Myotubes were transfected with the mRNA of the Coronin 6 and its mutants. Cell lysates were subjected to biotin-conjugated $\alpha$-BTX (Tox-P) for the precipitation of AChRs followed by Western blotting for FLAG. $\boldsymbol{E}, \boldsymbol{F}$, The cytoskeletal linkage of AChRs was reduced in myotubes overexpressing F-actin-binding-deficient Coronin 6 mutants. Myotubes were transfected with WT or mutant Coronin 6 mRNA and subsequently treated with agrin to induce AChR clusters. AChRs were then sequentially extracted by low and high concentrations of detergent as described in Materials and Methods. F, Percentages of AChR $\beta$ subunit extracted from the $1 \%$ Triton X-100 fraction. Quantification was performed in three individual experiments. * $p<0.05$ R29D versus Control or WT (Student's $t$ test). G-I, Overexpression of the Coronin $6 \Delta U C C$ mutant significantly attenuated agrin-induced AChR clustering. Representative images $(\boldsymbol{G})$, and quantification of the size $(\boldsymbol{H})$ and number $(\boldsymbol{I})$ of AChR clusters on myotubes from each condition. The mean \pm SEM of at least 3 experiments is indicated. ${ }^{*} p<0.05, \Delta U C C$ versus Control (Student's $t$ test). Scale bar, $50 \mu \mathrm{m}$.

\section{Coronin 6 regulates $\mathrm{AChR}$ clustering}

Because Coronin 6 is prominently expressed in skeletal muscle and concentrated at the postsynaptic sites of NMJs, we examined whether it regulates the process of AChR clustering. An siRNA (siCoro6) was designed to specifically knock down Coronin 6 expression in myotubes (Fig. 3A). Whereas agrin treatment induced robust AChR clustering in myotubes transfected with a control siRNA (an siRNA against the luciferase gene, siCont), 

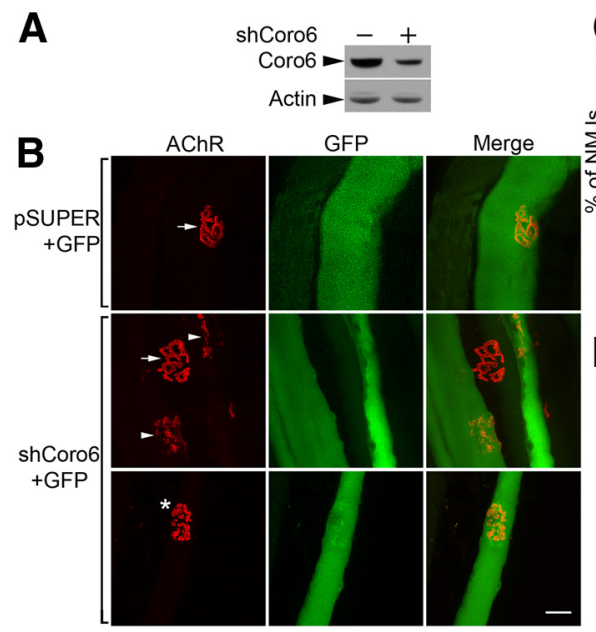

$\mathbf{E}$
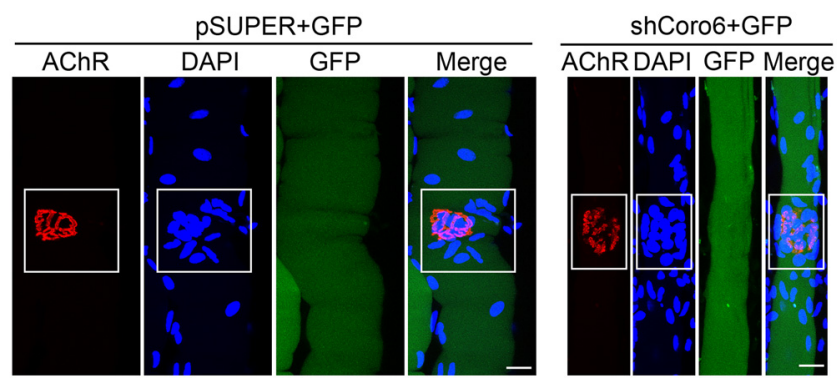

Figure 6. Coronin 6 knockdown perturbed AChR clustering in vivo. A, HEK-293T cells were cotransfected with Coronin 6 and pSUPER (-) or shCoro6 (+). Cell lysates were subjected to immunoblotting with antibodies against Coronin 6 or actin. $\boldsymbol{B}$, The tibialis anterior muscles of adult mice were injected with $5 \mu \mathrm{g} \mathrm{GFP}$ and $30 \mu \mathrm{g}$ pSUPER or shCoro6 followed by electroporation. Three weeks later, the muscles were stained with AlexaFluor-555-conjugated $\alpha$-BTX to visualize AChR clusters. GFP signals indicate the transfected skeletal muscle fibers. Arrows indicate the normal pretzel-like structures of the NMJ. Impaired NMJ structures, such as fragmented (arrowhead) and circular patch-like structures $\left({ }^{*}\right.$ ), were observed in Coronin 6-knockdown fibers. $C$ Percentages of NMJs exhibiting pretzel-like, fragmented, and circular patch-like shapes $(n=31$ from 4 mice injected with pSUPER $n=36$ from 4 mice injected with sh(oro6). D, Quantification of the size of AChR clusters. ${ }^{* *} p<0.01$, shCoro6 versus pSUPER (Student's $t$ test). $\boldsymbol{E}$, Clustering of nuclei at the subsynaptic regions was unaltered in Coronin 6-silenced muscle. Nuclei and AChR clusters were visualized by DAPI (blue) and AlexaFluor-555-conjugated $\alpha$-BTX staining (red), respectively. The subsynaptic regions are highlighted in rectangles. Scale bars, $20 \mu \mathrm{m}$.

Coronin 6 knockdown significantly reduced the number but not the size of agrin-induced AChR clusters (Fig. $3 B-D$ ). Furthermore, the relatively unchanged expressions of $A C h R$ subunits and myosin heavy chain proteins (data not shown) indicate that the observed defect in AChR clustering was not the result of the reduced expression of the receptor subunits or impaired muscle differentiation upon Coronin 6 knockdown.

Agrin is a master organizer for postsynaptic stabilization, and its removal results in the disassembly of AChR clusters. To verify whether Coronin 6 affects the maintenance of AChR clusters, we examined the disassembly of preexisting AChR clusters in Coronin 6-knockdown myotubes after agrin removal. The numbers of preexisting AChR clusters at 1,4 , and $12 \mathrm{~h}$ after agrin removal decreased remarkably in Coronin 6-knockdown myotubes compared with those in the corresponding control myotubes (Fig. $3 B, D$ ). Moreover, the disassembly rate during the first hour of agrin withdrawal was significantly higher in the Coronin 6-knockdown myotubes (Fig. 3E), suggesting that Coronin 6 also participates in the maintenance of AChR clusters.

In addition to agrin, laminins are important extracellular proteins that direct the maturation and maintenance of AChR clusters. In cultured myotubes, soluble laminins induced simple plaque-like AChR clusters resembling those induced by agrin, whereas substrate laminins initiated the formation of topologi- cally complex AChR clusters (i.e., perforated and branched clusters; Fig. $3 F, G$ ); these branched clusters resemble the pretzel-like AChR clusters in vivo (Kummer et al., 2004). Notably, Coronin 6 knockdown led to a significant reduction in the number of substrate laminininduced AChR clusters with complex morphologies (i.e., branched clusters) and a slight reduction in the number of perforated clusters; meanwhile, the induction of plaque-like clusters did not appear to be affected (Fig. $3 F, G$ ). These findings suggest that Coronin 6 is essential for the formation of topologically complex AChR clusters induced by substrate laminins.

\section{Coronin 6 regulates the AChR anchorage to the actin cytoskeleton} It is well established that pronounced molecular rearrangements, including reinforcement of the cytoskeletal anchorage of AChR clusters, occur at the subsynaptic regions during the formation and/or maintenance of NMJs (Moransard et al., 2003). Given that Coronin 6 is important for the formation and maintenance of AChR clusters, we examined whether Coronin 6 regulates the association of $\mathrm{AChR}$ clusters with the actin cytoskeleton. The tyrosine phosphorylation of the $\mathrm{AChR} \beta$ subunit is a signaling event associated with the actin cytoskeletal anchorage of the receptors (Borges and Ferns, 2001). Whereas agrin induced similar tyrosine phosphorylation of $\mathrm{AChR} \beta$ (p-Tyr-AChR $\beta$ ) in both control and Coronin 6-knockdown myotubes, agrin withdrawal in Coronin 6-knockdown myotubes resulted in a significant reduction of p-Tyr-AChR $\beta$ (Fig. 4A,B). Furthermore, we directly analyzed the strength of the interaction between AChRs and the actin cytoskeleton by sequential detergent extraction $(0.05 \%$ followed by $1 \%$ Triton X-100). Consistent with the decreased p-Tyr-AChR $\beta$, fewer AChRs were retained in 1\% Triton X-100 extracts from Coronin 6-knockdown myotubes upon agrin withdrawal (Fig. $4 C, D)$. These findings suggest that Coronin 6 plays an important role in the association between AChRs and the actin cytoskeleton during the maintenance of receptor clusters.

Given that coronins are conserved F-actin-binding protein family members and Coronin 6 regulates the actin cytoskeletal anchorage of AChRs, it is tempting to speculate that Coronin 6 associates with and regulates the receptor-linked actin cytoskeleton. Indeed, the results demonstrate that Coronin 6 binds to $\mathrm{F}$-actin in vitro and in $\mathrm{C} 2 \mathrm{C} 12$ myotubes, although this interaction is independent of agrin treatment (Fig. 4E,F). Whereas Coronin 6 was detected at low levels in AChR-associated complexes, agrin remarkably induced the recruitment of Coronin 6 to AChRs (Fig. $4 G)$. Interestingly, actin was present in the AChR-associated complex concurrent with Coronin 6 recruitment (Fig. 4G). These findings suggest that agrin induces the formation of an AChRCoronin 6-actin complex. 


\section{Coronin 6 regulates AChR clustering via its actin-binding activity}

Although different coronin members have distinct actin-binding sites, both the intact $\mathrm{N}$-terminal $\beta$-propeller domain and $\mathrm{C}$ terminus appear to be required for the full actin-binding activity of coronins (Uetrecht and Bear, 2006). To identify which domain(s) of Coronin 6 is responsible for its interactions with actin and AChR clusters, we generated two C-terminal truncation mutants of Coronin 6: one with the coiled-coil domain deleted ( $\Delta \mathrm{CC})$ and the other with both the unique region and coiled-coil domain deleted ( $\triangle$ UCC; Fig. 5A). Moreover, as a conserved Arg residue at the $\mathrm{N}$ terminus of Type I coronins (i.e., $\operatorname{Arg}^{29}$ in Coronin 6) is reported to be critical for high-affinity F-actin binding (Cai et al., 2007a), we constructed Coronin 6 mutants in which $\operatorname{Arg}^{29}$ was substituted with Ala or Asp (R29A/D).

Both the $\triangle \mathrm{CC}$ and $\triangle \mathrm{UCC}$ mutants failed to bind with actin, suggesting that the coiled-coil domain is essential for Coronin 6 -actin interaction. In addition, the R29A and R29D mutants exhibited substantially reduced Coronin 6-actin interaction (Fig. 5B). Importantly, the deletion of the coiled-coil domain or mutation of the $\operatorname{Arg}^{29}$ residue led to the complete disruption of the association between Coronin 6 and AChR clusters (Fig. $5 C, D)$. This suggests that the actin-binding activity of Coronin 6 is essential for its association with AChR clusters.

To determine whether the actin-binding activity of Coronin 6 is important for the cytoskeletal linkage of AChR clusters, wildtype or mutants of Coronin 6 were overexpressed in myotubes. Interestingly, C2C12 myotubes expressing the R29D mutant or $\Delta \mathrm{CC}$ truncation mutant exhibited reduced AChR cytoskeletal linkage, which was evidenced by decreased levels of AChRs retained in the more stringent detergent extraction (Fig. 5E,F). Although deletion of the coiled-coil domain of Coronin apparently did not affect the clustering of AChR induced by agrin, expression of the $\triangle U C C$ mutant of Coronin 6 (i.e., deletion of the unique region and coiled-coil domain) significantly reduced the agrin-induced AChR clustering (Fig. 5G-I). Together, these results indicate that the actin-binding activity of Coronin 6 is important for its association with AChR clusters and stabilization of the actin linkage of the receptors.

\section{Coronin 6 is important for the stabilization of AChR clusters in vivo}

To elucidate the physiological functions of Coronin 6 in the regulation of AChR clustering at the NMJ, Coronin 6 expression in the tibialis anterior muscle fibers of 4 -week-old mice was silenced by Coronin 6 shRNA (shCoro6). The knockdown efficiency of shCoro6 was confirmed in HEK293T cells coexpressing Coronin 6 with or without shCoro6 (Fig. 6A). Three weeks after electroporation, the untransfected and control vector (pSUPER)transfected muscle fibers exhibited typical pretzel-like AChR clusters with a complex array of branches (Fig. $6 B$ ). In contrast, fibers expressing shCoro6 exhibited severe fragmentation of AChR clusters, some of which even appeared as multiple disintegrated circular patches (Fig. $6 B, C$ ). Moreover, the average size of the NMJs was significantly smaller in Coronin 6-silenced muscle (Fig. 6D). Other features of NMJs, such as the clustering of subsynaptic nuclei, remained grossly normal in the Coronin 6-knockdown muscle (Fig. 6E). These results indicate that Coronin 6 is important for maintaining the proper structure of synaptic AChR clusters in vivo.

\section{Discussion}

The aggregation of AChR clusters at the postsynaptic membrane is a key event in NMJ development. Although these postsynaptic neurotransmitter receptors are thought to aggregate through anchoring to the actin cytoskeleton, the underlying regulatory mechanisms of this anchorage remain unclear. In the present study, we demonstrate that Coronin 6, a novel actin-binding protein enriched at the postsynaptic NMJ, regulates AChR clustering and stabilization by strengthening the AChR-cytoskeleton linkage. Thus, our results provide new insights into the molecular mechanisms involved in the regulation of AChR clustering during NMJ development.

The depolymerization of actin filaments interferes with AChR clustering, indicating that AChR clustering requires actin polymerization (Dai et al., 2000; Cartaud et al., 2011). A number of actin regulators, including actin-related protein-2/3 (Arp2/3) and Wiskott-Aldrich syndrome protein, are thought to be rapidly recruited to the AChR clusters upon agrin stimulation (Cartaud et al., 2011). Nonetheless, how these factors are recruited and subsequently lead to actin cytoskeletal rearrangement are largely unknown. In the present study, we show that either Coronin 6 suppression or disruption of the actin-binding activity of Coronin 6 resulted in the destabilization of AChR-actin linkage. This finding demonstrates a functional role of Coronin 6, which acts as a scaffolding protein in the formation of the AChR-actin complex. Given that coronins are actin-regulating protein family members, it is possible that the recruitment of Coronin 6 further acts on the remodeling of the AChR-anchored actin cytoskeleton. Type I coronins are capable of regulating actin dynamics through several mechanisms that involve Arp2/3, cofilin, and Rho GTPases (Humphries et al., 2002; Cai et al., 2005; Cai et al., 2007b; Castro-Castro et al., 2011). Consistent with this notion, we found that Coronin 6 interacts with the Arp2/3 complex in cultured myotubes (data not shown). However, whether Coronin 6 controls the receptor-associated actin dynamics via the modulation of Arp 2/3 complex activity remains to be determined.

As Coronin 6 is a novel coronin protein, whether its domains play similar roles as those of other coronins remains unclear. Concordant with the existing evidence that the $\beta$-propeller domain is a direct actin-binding interface of Type I coronins (Appleton et al., 2006), disrupting the intramolecular charge of the $\beta$-propeller domain of Coronin 6 by the mutation of Arg $^{29}$ abrogates actin binding. Another common function of the $\beta$-propeller domain is that it provides versatile sites for proteinprotein interactions (Stirnimann et al., 2010). Thus, the $\beta$-propeller domain of Coronin 6 may also act as a platform for multiple protein interactions, such as interactions with rapsyn and dystrophin-associated complex to strengthen the AChRactin anchorage. Therefore, further investigation is required to determine whether such a scaffolding role of the $\beta$-propeller domain is involved in AChR clustering and stabilization. Furthermore, our results show that the coiled-coil domain located at the C terminus of Coronin 6 is also important for its binding to actin. Consistent with the roles of the coiled-coil domains of other coronins, that of Coronin 6 is also important for the oligomerization of the protein (data not shown) (Humphries et al., 2002; Spoerl et al., 2002; Gatfield et al., 2005). In this case, the oligomerized Coronin 6 may play two important roles in AChR stabilization. First, the oligomerization reinforces the ability of Coronin 6 to regulate actin bundles and/or the actin network. Second, the oligomerization facilitates the scaffolding ability of Coronin 6 by providing more protein-protein interaction sites for recruiting 
critical regulators for AChR-actin anchorage. However, further analysis is required to identify the precise role of Coronin 6 oligomerization in AChR clustering.

The present study provides the first functional evidence of Coronin 6 in a mammalian system, revealing that it is a muscleenriched protein that regulates AChR clustering. Although different coronins exhibit distinct tissue-specific expression patterns, Coronin 6 is the only coronin prominently expressed in muscle. Interestingly, similar to other coronins, including Coronin $1 \mathrm{~A}, 1 \mathrm{C}$, and $2 \mathrm{~B}$, which are highly expressed in the brain, Coronin 6 expression is also observed within specific regions in the cortex and hippocampus (data not shown). Because of the high degree of conservation among the coronin family proteins, the present results may provide new insights for studying the roles of coronins in the regulation of neurotransmitter receptors at central synapses.

\section{References}

Aiyar A, Xiang Y, Leis J (1996) Site-directed mutagenesis using overlap extension PCR. Methods Mol Biol 57:177-191. CrossRef Medline

Appleton BA, Wu P, Wiesmann C (2006) The crystal structure of murine coronin-1: a regulator of actin cytoskeletal dynamics in lymphocytes. Structure 14:87-96. CrossRef Medline

Borges LS, Ferns M (2001) Agrin-induced phosphorylation of the acetylcholine receptor regulates cytoskeletal anchoring and clustering. J Cell Biol 153:1-12. CrossRef Medline

Cai L, Holoweckyj N, Schaller MD, Bear JE (2005) Phosphorylation of coronin $1 \mathrm{~B}$ by protein kinase $\mathrm{C}$ regulates interaction with Arp2/3 and cell motility. J Biol Chem 280:31913-31923. CrossRef Medline

Cai L, Makhov AM, Bear JE (2007a) F-actin binding is essential for coronin 1B function in vivo. J Cell Sci 120:1779-1790. CrossRef Medline

Cai L, Marshall TW, Uetrecht AC, Schafer DA, Bear JE (2007b) Coronin 1B coordinates Arp $2 / 3$ complex and cofilin activities at the leading edge. Cell 128:915-929. CrossRef Medline

Cartaud A, Stetzkowski-Marden F, Maoui A, Cartaud J (2011) Agrin triggers the clustering of raft-associated acetylcholine receptors through actin cytoskeleton reorganization. Biol Cell 103:287-301. CrossRef Medline

Castro-Castro A, Ojeda V, Barreira M, Sauzeau V, Navarro-Lérida I, Muriel O, Couceiro JR, Pimentel-Muíños FX, Del Pozo MA, Bustelo XR (2011) Coronin 1A promotes a cytoskeletal-based feedback loop that facilitates Racl translocation and activation. EMBO J 30:3913-3927. CrossRef Medline

Chan KT, Creed SJ, Bear JE (2011) Unraveling the enigma: progress towards understanding the coronin family of actin regulators. Trends Cell Biol 21:481-488. CrossRef Medline

Dai Z, Luo X, Xie H, Peng HB (2000) The actin-driven movement and formation of acetylcholine receptor clusters. J Cell Biol 150:1321-1334. CrossRef Medline

de Hostos EL (1999) The coronin family of actin-associated proteins. Trends Cell Biol 9:345-350. CrossRef Medline

de Hostos EL, Bradtke B, Lottspeich F, Guggenheim R, Gerisch G (1991) Coronin, an actin binding protein of Dictyostelium discoideum localized to cell surface projections, has sequence similarities to G-proteinbeta subunits. EMBO J 10:4097-4104. Medline

Dobbins GC, Zhang B, Xiong WC, Mei L (2006) The role of the cytoskeleton in neuromuscular junction formation. J Mol Neurosci 30:115-118. CrossRef Medline

Föger N, Rangell L, Danilenko DM, Chan AC (2006) Requirement for coronin 1 in $\mathrm{T}$ lymphocyte trafficking and cellular homeostasis. Science 313:839-842. CrossRef Medline

Fu AK, Smith FD, Zhou H, Chu AH, Tsim KW, Peng BH, Ip NY (1999) Xenopus muscle-specific kinase: molecular cloning and prominent ex- pression in neural tissues during early embryonic development. Eur J Neurosci 11:373-382. CrossRef Medline

Gatfield J, Albrecht I, Zanolari B, Steinmetz MO, Pieters J (2005) Association of the leukocyte plasma membrane with the actin cytoskeleton through coiled coil-mediated trimeric coronin 1 molecules. Mol Biol Cell 16:2786-2798. CrossRef Medline

Humphries CL, Balcer HI, D’Agostino JL, Winsor B, Drubin DG, Barnes G, Andrews BJ, Goode BL (2002) Direct regulation of Arp2/3 complex activity and function by the actin binding protein coronin. J Cell Biol 159: 993-1004. CrossRef Medline

Ip FC, Fu AK, Tsim KW, Ip NY (1995) Cloning of the alpha component of the chick ciliary neurotrophic factor receptor: developmental expression and down-regulation in denervated skeletal muscle. J Neurochem 65 : 2393-2400. CrossRef Medline

Ip FC, Fu AK, Tsim KW, Ip NY (1996) Differential expression of ciliary neurotrophic factor receptor in skeletal muscle of chick and rat after nerve injury. J Neurochem 67:1607-1612. CrossRef Medline

Kummer TT, Misgeld T, Lichtman JW, Sanes JR (2004) Nerve-independent formation of a topologically complex postsynaptic apparatus. J Cell Biol 164:1077-1087. CrossRef Medline

Lee CW, Han J, Bamburg JR, Han L, Lynn R, Zheng JQ (2009) Regulation of acetylcholine receptor clustering by $\mathrm{ADF} /$ cofilin-directed vesicular trafficking. Nat Neurosci 12:848-856. CrossRef Medline

Moransard M, Borges LS, Willmann R, Marangi PA, Brenner HR, Ferns MJ, Fuhrer C (2003) Agrin regulates rapsyn interaction with surface acetylcholine receptors, and this underlies cytoskeletal anchoring and clustering. J Biol Chem 278:7350-7359. CrossRef Medline

Mueller P, Massner J, Jayachandran R, Combaluzier B, Albrecht I, Gatfield J, Blum C, Ceredig R, Rodewald HR, Rolink AG, Pieters J (2008) Regulation of $\mathrm{T}$ cell survival through coronin-1-mediated generation of inositol1,4,5-trisphosphate and calcium mobilization after $\mathrm{T}$ cell receptor triggering. Nat Immunol 9:424-431. CrossRef Medline

Pieters J, Müller P, Jayachandran R (2013) On guard: coronin proteins in innate and adaptive immunity. Nat Rev Immunol 13:510-518. CrossRef Medline

Sadasivam G, Willmann R, Lin S, Erb-Vögtli S, Kong XC, Rüegg MA, Fuhrer C (2005) Src-family kinases stabilize the neuromuscular synapse in vivo via protein interactions, phosphorylation, and cytoskeletal linkage of acetylcholine receptors. J Neurosci 25:10479-10493. CrossRef Medline

Sanes JR, Lichtman JW (1999) Development of the vertebrate neuromuscular junction. Annu Rev Neurosci 22:389-442. CrossRef Medline

Sanes JR, Lichtman JW (2001) Induction, assembly, maturation and maintenance of a postsynaptic apparatus. Nat Rev Neurosci 2:791-805. CrossRef Medline

Shi L, Butt B, Ip FC, Dai Y, Jiang L, Yung WH, Greenberg ME, Fu AK, Ip NY (2010) Ephexin1 is required for structural maturation and neurotransmission at the neuromuscular junction. Neuron 65:204-216. CrossRef Medline

Shi L, Fu AK, Ip NY (2012) Molecular mechanisms underlying maturation and maintenance of the vertebrate neuromuscular junction. Trends Neurosci 35:441-453. CrossRef Medline

Spoerl Z, Stumpf M, Noegel AA, Hasse A (2002) Oligomerization, F-actin interaction, and membrane association of the ubiquitous mammalian coronin 3 are mediated by its carboxyl terminus. J Biol Chem 277:48858 48867. CrossRef Medline

Stirnimann CU, Petsalaki E, Russell RB, Müller CW (2010) WD40 proteins propel cellular networks. Trends Biochem Sci 35:565-574. CrossRef Medline

Tang H, Cheung WM, Ip FC, Ip NY (2000) Identification and characterization of differentially expressed genes in denervated muscle. Mol Cell Neurosci 16:127-140. CrossRef Medline

Uetrecht AC, Bear JE (2006) Coronins: the return of the crown. Trends Cell Biol 16:421-426. CrossRef Medline

Wu H, Xiong WC, Mei L (2010) To build a synapse: signaling pathways in neuromuscular junction assembly. Development 137:1017-1033. CrossRef Medline 